\title{
SMALL AND MEDIUM-SIZED ENTERPRISES IN REPUBLIC OF MOLDOVA
}

\author{
Igor G. SîRODOEV \\ Institute of Geography, Chisinau, Republic of Moldova
}

\begin{abstract}
The paper examines the role of SME sector in Moldova's economy and its likely implications in the RD processes. Several key features of the relationship between knowledge economy, RD and SMEs are emphasized, and also their effect on regional and local communities. Then, a summary of RD particular features in Moldova is presented. The role of SME sector, examined in terms of its performance by ownership and activity types, as a whole and by main firms' categories (micro-, small, and medium-sized) is analyzed. Small enterprises have been considered as the most adequate solution for promoting RD in general case. National-level analysis is completed by regional insight into the sector as a whole. Finally, some critical aspects of SMEs' role in RD in Moldova are discussed.
\end{abstract}

Key Words : small and medium-sized enterprises, enonomy, Moldova.

\section{Importance of small and medium-sized enterprises for regional development}

Regional development (RD) represents downscaling economic processes in order to address the needs of regional and local communities. It is seen as an appropriate instrument, especially in Europe, for promoting development of the regions and diminishing discrepancies within countries. Italian's and Greece's experience of governmental regulation of RD processes has shown that state implication into this problem is not a quite successful solution. Therefore, concepts of the region have been restructured at the European level, being considered as an appropriate operational space for focusing objectives, funds distribution and project implementation (lanoş and Heller, 2006). The region is still considered as a territorial base for national economic growth, as localization of such a growth. However, the accent in region's view has been progressively moving from a planning unit to a self-structured entity.

With the rise of "knowledge economy" (Cooke, 2002) learning becomes the most profitable advantage of an economic entity, while "innovation becomes crucial term in international technical-economic competition' (Lundval, Johnson, 1994). In such a way, region's "learning capacity" becomes critical factor in the modern approach to regional development. How can this capacity be enhanced?

Baumol (2004), for example, has pointed out that small and medium-sized enterprises (SMEs) have an important role to play in the innovation process, especially as the source of new inventions that are usually taken up to be developed and diffused throughout the economy by larger companies. Following this mainstream idea, EU have reconsidered the role of SME sector, the development of the latter has become a central pillar of the Lisbon Agenda to increase dynamic character and competitiveness of the European economy by 2010 
(EC Commission, 2005). Increasing regions' learning capacity, according to the same document, is considered through, among others, developing innovation poles linking regional centers, universities and business.

Moreover, I. lanoş and W.Heller (2006) emphasize three the most innovative actors at the regional level, considering "...that SMEs, as palpable products of the local, that regional institutions, as regulators of the network of places, and universities, as a result of existence of critical population mass and actors of socio-economic life, are main generators of knowledge".

Assessing briefly the impact of the three key factors of knowledge production in Moldovan regional development, we can summarize the following:

- Regional institutions are not consolidated, due to the particularities of Moldavian administrative and territorial organization and to the absence of regional administrative authorities (Sirodoev, 2007);

- Universities are concentrated mainly in capital city, and the "critical mass" at the regional scale cannot be achieved in the will make possible an emergence of the genuine network of regional universities in the near future (especially in the south);

- Small and medium-sized enterprises are mainly concentrated in Chisinau and their regionally differentiated contribution to development, although varied, is characterized by the general trend of weakness.

Apparently, none of the key factors/actors of the knowledge production is favorable for Moldova. However, when promoting knowledge economy, in this particular case, extending the SME sector would require the lowest investments and result in quicker profit. Indeed, the SME sector has lesser dependency on a "critical mass", does not require redrawing administrative organization of the country, has enjoyed legal support almost since the very beginning of market economy in the country (for about 14 years). In such a way, SMEs become one of the best choices to provide knowledge production in national economy. But why are they particularly important for regional development?

If we consider that regional development achieves overall development of the country by addressing and satisfying regional and subregional needs, then there is a need of certain structures to perceive and solve the latter. In the market economy, promoted in Moldova, such structures should be a part of the market system, and SMEs entirely fit this requirement.

On the one hand, SMEs are very sensitive to local and regional circumstances; on the other hand, they are able to solve local and regional problems following interests of local communities (lanos and Heller, 2006). They act in local/regional space, and "good health" of this space contributes to their prosperity as well. There is a clear relation of feed-back, having the highest intensity in the case of small enterprises.

Two types of activities should be differentiated by their impact on RD. Production is needed to attract external flows into the region for further development. However, production strongly depends on local resources (especially, material) and is less sensitive to local problems. Services mainly depend on human resources and are less dependent on materials. They are more sensitive to local/regional needs and can better solve the latter. However, it is very likely that services, in the case of Moldova, will bring less external investments.

In its turn, the SME sector, regardless of the type of activity, has different impact depending on the size of firms as well. Micro-enterprises clearly depend on the local circumstances and are 
able to solve specific needs in only two cases: acting within associations or at sub local level (street, neighborhood). Small enterprises optimally work with the authorities in the case of local communities, sometimes abiding to the local requirements, sometimes positively responding to local challenges. They are preferable for small to medium-sized communities. Medium-sized enterprises play better their role in the case of medium-sized to large communities, where small companies have insufficient financial or human capacity.

Of course, there are many problems faced by the SME sector in its contribution to the economic development of the country and they cannot be resolved in every case. However, SMEs have definitely a positive effect on equitable development of local communities (Jeppesen, 2005).

Having pointed out the role of the SME sector in global and local processes, we should answer the question: what about regional development?

\section{Regional development in Moldova: summary ${ }^{1)}$}

Regional development is a new issue for the post-Soviet Moldova. Historically speaking, Moldova has traditionally had two approaches to administrative-territorial organization regional (based on counties) and raional (based on the classic Soviet administrative-territorial units). The raional pattern has a greater impact on the present situation that would be cost-intensive to change.

Regional disparities, accentuated during the transition period, highlight the opposition of the capital city to the rest of the country (not as impressive as in Hungary, but still important), the double exposure of monoindustrial towns to poverty, and political conflict in the eastern part of the country. To diminish these discrepancies, an EU-based institutional structure for the coordination of the RD process is being implemented, but it is in early stages, with limited effects by now. "Standard" RD policy objectives, common to many other eastern European countries, are the basis of the national RD policy. But the latter does not have an appropriate framework for implementation due to the incipience of regional structures and the lack of clear separation between regional/local and central competences.

Main RD related problems occur in planning, public administration and local public finance. Problems of RD organization and planning refer to fragmentation of central authorities, which have weak cooperation at the same level; the lack of a clear view on RD related issues results in vagueness and absence of clear solutions to be applied. Public administration problems include increased fragmentation, which accentuates the alveolation of the settlement system; the small size of local budgets and limited qualified human resources; deconcentration preferred instead of decentralization; and lack of stability in administrative-territorial organization. All these result in a dependency on central authorities and even in the formation of the dependent mentality. Local public finance problems affect equalization schema, extra revenues threshold (just $10 \%$ of local authorities enjoy them), restrict possibilities of local investments, increasing the reduction of capital investment from local budgets, and the instability of state support policy. Special issues refer to the frozen internal political conflict in the eastern part of the country, insufficient cross-border cooperation within the euro-regions, and labor force migration that causes social and economic problems common to many other eastern European countries. given.

1) Mainly drawn on Sirodoev, 2007 , in which an extensive analysis of the RD issue in Moldova is 


\begin{abstract}
Within the last year, the RD law was finally adopted. It creates the legal framework for the implementation of regional policies. As expected, this law presents many drawbacks and unclear formulations and needs to be improved. The most important drawback consists in the law's non-universal character: not all the administrative-territorial units fall under the force of the law. Six regions of development have been created, being differentiated in the most logical way: region of development "South" (SRD), region of development "Center" (CRD), and region of development "North" (NRD). This separation has been made following more or less precisely the lines of soviet traditional territorial-economic organization structures - economic regions. The other three regions were created relying on the political logic: Chisinau, Transnistria, and Gagauzia. The latter declined the idea of forming one and the same region of development with southern raions. Its decision is based on relative financial and political autonomy. Therefore, the southern part of the country will still be very fragmented and all administrative and financial efforts will be divided between the two regions, none of which is able to compete with other regions of development.
\end{abstract}

In order to overcome the current problems, the identification of effective RD policies is needed. According to the identified needs, an appropriate theoretical concept using EU and non-EU best practices should be adopted and appropriate institutional structures (the Romanian, Polish or Slovenian examples, adjusted for local circumstances, would be suitable) should be created to increase the flexibility of the RD process. At the same time, planning instruments should set a general framework rather than a detailed action plan, putting an accent rather on the selfstructuring capacity of regions than on planned measures. More competences, responsibilities, and financial resources should be assigned to the local and regional levels of administration, in this way the needed flexibility will be achieved. RD funding should be secured by a specifically designated fund, financed from various types of sources. In addition, RD related policies should include a framework for solving political conflicts. Cross-border cooperation should be broadened, first of all, but not limited, to ecological and tourist oriented cooperation. Our final recommendation is that the main problems of labor force migration and remittances are not how to bring them to an end, but rather how to use them with greater benefit to the country. If conditions are created for attracting remittances to the economy with a preference for productive investment rather than financing household consumption, the question of working abroad will shift, in our opinion, from a keen necessity to an optional choice.

A possible way to achieve the proposed recommendations consists in developing the SME sector. It has an advantage of being the most flexible part of national economy. The SME sector is the most appropriate for investing remittances, because it does not require big amounts of money. But, at the same time, the effect of such investments will overpass the limits of this sector.

Developing the SME sector in underdeveloped areas will increase economic capacities and financial independence of local communities, creating the base for their adequate self-reliant development. Development of local market and self-reliance will contribute to the intensification of relationships between settlements within the economic space. It will lead to diminishing the intensity of alveolation and destructive fragmentation within the national settlement system in the favor of increasing integration processes, especially on the medium and lower hierarchical tiers of the national settlement system (Sirodoev, 2006a). But a well-integrated, "healthy" settlement system, as a lofty goal, is a reflection of "healthy" economy. In such a way, it is expected that, through developing the SME sector, regional policies will achieve better results by the most efficient use of local resources.

Thereupon, the main purpose of this paper consists in analyzing the present state of the SME sector in order to show-up its sensible features appropriate for promoting a national 
RD policy.

\section{Moldova's SME sector: introduction}

The SME sector plays a very important role in national economy: by 2007 , it has included $98.3 \%$ of all the enterprises registered in the country. Almost $60 \%$ of employees in the national economy work in SMEs. Micro-, small and medium-sized enterprises have a share of $45 \%$ in the all enterprises' turnover (revenues from sales) and bring $35 \%$ of the all enterprises' profit. In absolute values, the above figures for SME sector are as follows: 39.3 thou. enterprises, 343.5 thou. employees, 66.8 bil. MDL (about 5.5 bil. USD) of turnover and 3.8 bil. MDL (about 0.3 bil. USD) of net profit before taxation.

Legal background. Since the beginning of the transition period, legal facilitation of business activities of small firms has been being one of the national authorities' greatest concerns. The very first law regarding facilitating small business was adopted in 1994 (Legea nr. 112XII/20.05.1994). Under the force of law were only micro- and small enterprises as juridical people having fewer than 50 employees.

In 2006, the new law on small and medium-sized enterprises (SMEs) came into force (Legea nr. 206-XVI/7.07.2006). This way, business facility has been extended on the medium sized enterprises as well, following the threshold used by the EU. The new group should comply with three criteria: maximal manpower should be fewer than 250 employees, annual revenues from taxes (turnover) should be less than 50 mil. MDL and total annual assets should be less than 50 mil. MDL. Compared to the previous situation, the new law has added under the force of law physical people with an economic activity and corresponding to the criteria mentioned above, as well as all kind of non-commercial organizations and producers of excisable goods. Several types of firms do not enjoy facilitations from this law: dominant enterprises in their economic sector, insurance, financial and gambling companies, investment funds, exchange offices, and firms, having among their founders or shareholder (with shares exceeding $35 \%$ ) legal or physical people that do not comply with the present law. Finally, of course, the law is applied to the firms with entirely private capital.

The organization for developing the SME sector, under the Ministry of Economy and Trade, is responsible for the implementation of specific national policies. Special funds serve as financial provision of national policies in the field. There is no specific fund created or budget quota allotted for this purpose. Generally, the new situation is not as liberal as it was under the previous law. In particular, local administration is not quite free to promote SMEs from the sector it considers useful to local communities, but needs to coordinate their activities with the central authorities and national policies. Virtually, this situation confines somehow SMEs restructuring activities within local communities in their economic aspect. Therefore, interests of local communities are subordinated to the national ones.

In total, we cannot say how many firms are subject of this law as long as we do not have data on the share of shareholders. However, there are 38.6 thou. of non-public firms (more than $98 \%$ of all SMEs) that can be potentially included under the force of the law.

The Government recognizes that SMEs represent an important part of the knowledge economy to be created and promoted in Moldova. Since 2006 it has extended and varied its activities for facilitating and promoting small and medium-sized business by diversifying legal background and adopting strategies related to SMEs. At the same time it is aware of the poor situation and underdevelopment of the SME sector, pointing out the following main problems: restrained 
access to financial sources, especially to long-term credits, lack of the pledge needed for applying for credits, and underdeveloped entrepreneurial culture (National strategy of development for 2008-2011).

In order to solve these problems and promote further development of the SME sector, the Government has planned for the following four years to implement more or less radical measures particularly focused on SMEs (National strategy of development for 2008-2011):

- create the legal and institutional background;

- facilitate access to credits;

- develop entrepreneurial spirit through education;

- extend consultation services;

- stimulate innovating culture;

- intensify the public-private dialog;

- set a special accent on facilitating SMEs in rural areas.

Governmental actions for facilitating activities within the SME sector have a double impact. On the one hand, there is no doubt that their contribution is quite beneficial for the enterprises in this sector (and the example of the performance of medium-sized enterprises recently included under the law is very suggestive in this regard). On the other hand, the Ministry of Economy and Trade recognizes that these measures are far from being satisfactory and very special attention should be paid to this sector in the future (National strategy of development for 2008-2011).

Although there is an apparent balance between lofty and practical goals in the legal documents (especially national and sectoral strategies and action plans), civil society and eco-nomic actors have justified doubts about the successfulness of their implementation. Moreover, imbalances between declared goals and accomplished objectives constitute one of the most significant political problems in Moldova (Mocanu, 2007) $)^{2}$. This situation is caused not just by bad intentions/incompetence of central authorities, but by low activity of local public administration as well. For instance, according to the governmental annual report on the first year of implementation of the latest Strategy particularly focused on SMEs (Strategy on supporting SMEs development for 2006-2008) central authorities had initiated actions within all five strategic objectives of the document in 2006. However, none of the local authorities had implemented measures within all the objectives. Many ATUs had not implemented any action in accordance to the Strategy (Drochia, Floresti, Ocnita, Gagauzia). Special attention should be paid to the fact that raions where the SME sector is the least developed (Soldanesti, Telenesti, Singerei, Causeni, Stefan-Voda) had not done anything for its promotion on their territories. In their turn, ATUs more or less actively involved in implementing the objectives of the Strategy at the SMEs level show performance above the country average (Chisinau, Balti, Briceni, Hincesti, Orhei, Straseni).

Bearing in mind this dichotomy of the governmental measures' effects, it is quite hard to make a credible prognosis of the impact of legal background on the SME sector. However, one could expect positive impact of such measures for the entire sector followed by rising territorial imbalances of the SMEs' performance.

Short description of quantitative data. The sector of small and medium-sized enterprises in

2) It is curios that this publication does not include the situation within the SMEs sector among the most significant problems having been faced by Moldova in 2007. 
Moldova enjoys separate statistical monitoring as long as it falls under the force of the specific law. The latest act, adopted in May 2006, has extended business facility on the medium-sized enterprises as well. Before that date, just for 2005 some of the indicators have been calculated retrospectively. In such a way, available sequence of data goes back for three years. In the case of small and micro-enterprises this sequence is longer, but is not differentiated by firm categories and its analysis in the perspective of the new law is almost useless.

Primary quantitative data, presented in the paper, have been extracted from NBS's (National Bureau of Statistics) public sources: statistical yearbooks and specific information notes (BNS, 2006; BNS, 2007; BNS, 2008), being further processed. This short period does not allow making a credible analysis of the sector's temporal dynamics; therefore, it has been involved in a very restraint manner.

General characteristics. The structure of SME sector by categories of enterprises varies depending on the indicator. In terms of the total number of units, micro-enterprises dominate with no doubt (table 1). This unevenness is not as clear in the distribution of the number of employees, where medium-sized enterprises have the highest proportion (slightly more than $40 \%$ ). In the distribution of turnover and profit small enterprises have the greatest share; however, their role is not exclusively dominant due to the important contribution of mediumsized enterprises.

Table 1

Characteristics of the categories of enterprises within the SME sector in 2007

\begin{tabular}{|c|c|c|c|c|c|c|c|c|}
\hline \multirow{2}{*}{$\begin{array}{c}\text { Firm } \\
\text { category }\end{array}$} & \multicolumn{2}{|c|}{$\begin{array}{l}\text { Number of } \\
\text { enterprises }\end{array}$} & \multicolumn{2}{|c|}{$\begin{array}{c}\text { Average number of } \\
\text { employees }\end{array}$} & \multicolumn{2}{|c|}{ Turnover } & \multicolumn{2}{|c|}{ Profit } \\
\hline & thou. units & $\%$ & thou. pers. & $\%$ & mil. $M D L$ & $\%$ & mil. $M D L$ & $\%$ \\
\hline Medium & 1.8 & 4.6 & 140.8 & 41.0 & 24881.2 & 37.3 & 1486.0 & 39.3 \\
\hline Small & 7.2 & 18.3 & 111.7 & 32.5 & 30230.0 & 45.3 & 1855.1 & 49.1 \\
\hline Micro & 30.3 & 77.1 & 91.0 & 26.5 & 11675.4 & 17.5 & 436.4 & 11.6 \\
\hline SME sector & 39.3 & 100.0 & 343.5 & 100.0 & 66786.6 & 100.0 & 3777.5 & 100.0 \\
\hline
\end{tabular}

Source: National Bureau of Statistics

If we look inside the characteristics using specific indices, the situation appears to be different. The average size of a firm within the SME sector is nine employees, only because of the domination of the micro-enterprises in the sector's structure. At the same time, mean mediumsized firms have 78 employees, 16 people work in a mean small firm, while a mean micro-enterprise consists of three workers. Similar differentiation appears when analyzing other indices as well. Revenues (turnover) per enterprise depend on the firm's size: the highest figure is in the mean medium-sized firm (almost 14 mil. MDL), the lowest one is in the mean micro-enterprise (about 0.4 mil. MDL), while the mean small enterprise is somewhere in the middle with 4 mil. MDL. Revenues per person, that reflect employees' efficiency, change the hierarchy. It appears that the personnel is used the most efficiently in the small firms, where every person is responsible for 270 thou. MDL, 1.5 time more than in the medium-sized enterprises placed secondly (177 thou. MDL); micro-enterprises are on the third place with 128 thou. MDL. Theamount of profit per employee has the same distribution: every person in small firms brings almost 17 thou. MDL (more than 1 thou. EUR), while in medium-sized firms this figure is just 10.6 thou. MDL, and in micro-enterprises it is less than 5 thou. MDL. This efficiency in using the personnel is reflected on firms' profitability (share of profit in turnover): 
medium-sized and small enterprises are quite close (5.97\% and $6.14 \%$ accordingly), while profitability of micro-enterprises is slightly lower $(3.7 \%)$. In such a way, we can conclude that small enterprises plays very important role in the SME sector, being, at the same time the sector's most efficient category.

The SME sector is continuously growing: the number of SME has increased by $11 \%$, amount of turnover has risen by $23 \%$ and net profit has increased by $116 \%$ in the last year. However, the situation is different for the three groups of firms within this sector. While microand small enterprises have shown constant progress in the last 5 years, figures for mediumsized enterprises did not look as optimistic until their inclusion in the new law. Undoubtedly, extending business facilitating over the entire SME sector will bring benefits to the mediumsized enterprises as well, and first signs of improving their financial situation appear already in their evolution in 2007. It refers especially to the turnover of the firm. On the general slowingdown trend of decreasing number of medium-sized enterprises and employees within, the increase of the amount of revenues and profit in 2007 is remarkable especially because of the highest figures in the sector (30\% vs. $28.5 \%$ for micro-enterprises and $16.8 \%$ for small firms in the case of turnover and $153.1 \%$ vs. $74.7 \%$ and $103.6 \%$, accordingly, in the case of profit).

Examining the specific indicators, we distinguish signs of the same trends described above. The general trend of change reflects rising efficiency and dynamics of the entire sector. Once again, small enterprises represent the sector's pivot with a constant growing trend. However, medium-sized enterprises, after extending the law on business facilitating over them, show the highest figures of growth. For instance, comparing them to the secondly placed category: $22 \%$ vs. $16 \%$ for micro-enterprises in the case growing revenues per firm, $31 \%$ vs. $16 \%$ for micro-enterprises in the case of increasing personnel efficiency or $96 \%$ vs. $74 \%$ for small enterprises in the case of rising profitability. Should we expect that medium-sized enterprises would replace in a couple of years small ones in their role of SME sector's pivot? It will be possible to answer this question just after the law on SME sector will have been in force several more years.

\section{Ownership structure of SMEs}

Statistical monitoring allows us analyzing SME sector by two key parameters: ownership and activity structure. Five types of ownership are monitored: public (entirely public capital), private (entirely private national capital), mixed (public and private national capital in different proportions), foreign (with capital originated completely outside the country), and joint ventures (enterprises with mixed, national and foreign, capital). In the following analysis we will operate with these terms, opposing, for instance, private firms to foreign and so on, although both, in absolute terms, can be private.

Contribution to the market. Among the total number of 39.3 thou. enterprises (Table 2) private ones, having the proportion of about $90 \%$, dominate the entire sector, followed at a very big distance by enterprises with participation of foreign capital of various shares (almost $8 \%$ ) and enterprises with public capital of various shares (less than $2 \%$ ).

In terms of other indicators, these figures slightly change but general situation is the same, evidencing clear domination of SME with private capital; differences are produced just because of fighting for second place. For instance, if we speak about average number of employees, 
Ownership structure of the SME sector's enterprises in 2007

\begin{tabular}{|c|c|c|c|c|c|c|c|c|}
\hline \multirow{2}{*}{$\begin{array}{c}\text { Type of } \\
\text { ownership }\end{array}$} & \multicolumn{2}{|c|}{ Number of enterprises } & \multicolumn{2}{|c|}{$\begin{array}{c}\text { Average number of } \\
\text { employees }\end{array}$} & \multicolumn{2}{|c|}{ Turnover } & \multicolumn{2}{|c|}{ Profit } \\
\hline & thou. units & $\%$ & thou. pers. & $\%$ & mil. $M D L$ & $\%$ & mil. $M D L$ & $\%$ \\
\hline Public & 0.7 & 1.8 & 27.3 & 7.9 & 1707.6 & 2.6 & 150.0 & 4.0 \\
\hline Private & 35.3 & 89.8 & 275.3 & 80.1 & 56199.5 & 84.1 & 3331.9 & 88.2 \\
\hline Mixed & 0.3 & 0.8 & 9.7 & 2.8 & 741.7 & 1.1 & 96.1 & 2.5 \\
\hline Foreign & 1.4 & 3.6 & 15.3 & 4.5 & 3548.1 & 5.3 & 43.9 & 1.2 \\
\hline Joint ventures & 1.6 & 4.1 & 15.9 & 4.6 & 4589.7 & 6.9 & 155.6 & 4.1 \\
\hline Total SME & 39.3 & 100.0 & 343.5 & 100.0 & 66786.6 & 100.0 & 3777.5 & 100.0 \\
\hline
\end{tabular}

Source: National Bureau of Statistics

private enterprises embrace about $80 \%$ of employees in SME sector; on the second place are situated enterprises with public capital (almost 11\%), while enterprises with foreign capital (having more than $9 \%$ of employees) occupy just the third place. A similar hierarchy is observed when analyzing the profit: private on the first place ( $88 \%$ of the SME sector's profit), public participation (6.5\%) and foreign participation (slightly more than $5 \%$ ). However, this situation changes if we analyze revenues: private enterprises $(84 \%$ of the SME sector's revenues) are followed firstly by firms with foreign capital $(12 \%)$ and secondly by firms with public capital $(4 \%)$.

Across the categories of firms, private companies exclusively dominate compared to other types of ownership: from $92 \%$ of all micro-enterprises to $72 \%$ of all medium-sized enterprises. Companies with participation of foreign capital are on the second place in the categories of small $(8 \%)$ and micro-enterprises $(7 \%)$, while public companies are second numerous among medium-sized firms (almost 17\%). In terms of average number of employees, values of difference have the same order: domination of private companies falls in the range of $70-91 \%$. Next succession is similar to the previous with slight difference of figures: public companies embrace about $1 / 5$ of employees in medium-sized enterprises, while companies with participation of foreign capital occupy the second place with $8 \%$ in each of the remaining categories. As for turnover, foreign companies definitely occupies the second place (obviously, after private ones). Share of private companies in the total categories' turnover falls within the range of $76-90 \%$, while share of foreign companies varies from $16 \%$ among medium-sized enterprises to $10 \%$ in each of small and micro-enterprises. Companies with the participation of public capital occupy the last place with quite small values (only their share among the medium-sized enterprises is a little bit bigger - about $7 \%$ ).

The distribution of profit is completely different. Although private companies play the leading role across categories, we should emphasize losses of micro-enterprises with participation of foreign capital (foreign enterprises had lost in 2007 about 30 mil. MDL, while joint ventures about 11 mil. MDL) in the proportion of about $12 \%$ of the micro-enterprises' profit. However, in 2006, public and mixed companies and joint ventures within the category of micro-enterprises had ended the year with losses, while foreign companies had contributed to the category's profit by 21 mil. MDL (about $8 \%$ of the category's profit). In the case of small and medium-sized enterprises, the trend is apparently more stable. The share of private enterprises varies from $78 \%$ to $91 \%$. Public enterprises had a contribution of $13 \%$ (comparing to $9 \%$ of the companies with foreign capital) to the medium-sized enterprises' profit and of $3 \%(6 \%$ in the case of 
companies with foreign capital) to the small companies' profit.

The issue of profit is quite controversial. In our opinion, it should be assessed as a moving average sum at least for three years. However, we do not have the necessary sequence of data; only information for the two last years is available. The year of 2006 was very difficult in SME sector, and many categories of firms ended it with losses. From this viewpoint, 2007 was much better. In such a way, profit and profitability varies very much from year to year and should not be considered as constant for certain type of enterprise.

One important conclusion follows from this analysis: the SME sector is definitely dominated by private companies. At the same time, companies with participation of foreign capital follow them as turnover across all the firm categories. Public capital is more interested in mediumsized enterprises where its contribution is higher (especially to employment - 1/5 of all the employees).

Efficiency assessment. Looking inside specific indicators allows us emphasizing some particular features among the ownership types of the entire SME sector. Firstly, we should remark large size of the enterprises with participation of public capital (especially, in the medium-sized category): 39 people in the case of entirely public firms and 32 people in mixed ones. On the second level, enterprises with foreign capital have 11 employees in foreign firms and 10 people per average joint venture. Private firms are the smallest - just 8 employees per firm in the entire SME sector.

This hierarchy roughly maintains within the categories of firms; however, some changes appear on the lower levels. The category of medium-sized enterprises public firms has the largest, with 102 employees on average. They are followed by joint ventures (81 empl. on average), then private and foreign (76 people and 73 people accordingly), and, finally, by mixed enterprises (68 people per enterprise). The enlargement of foreign enterprises in the last 2-3 years is quite remarkable, against reducing in size firms with local capital. Small enterprises show the same domination in size of firms with public capital ( 26 people for mixed and 19 people for public); firms with private and foreign capital are quite close to each other, having on average 14-16 people per enterprise. Inside the category of micro-enterprises the hierarchy pulls out public enterprises on the first place (6 employees per enterprise), followed by foreign ( 4 people) and other types with 3 people on average per firm.

As a common feature for the size of enterprises, we should remark the domination of the firms with participation of public capital; they can be bigger, on average, than other categories by 25 $65 \%$ depending on the category. For the entire SME sector this figure is equal to about 2.5 times. At the same time, private companies are constantly among the smallest in the sector, while enterprises with foreign capital change their position in the hierarchy from category to category.

Analyzing the overall turnover per enterprise in the SME sector, we see the hierarchy changed. Joint ventures are those that operate, on average, with the largest amount of revenues (2.9 mil. MDL) followed by foreign firms (2.5 mil. MDL per firm). Enterprises with public participation are on the third place with $2.4 \mathrm{mil}$. MDL, and private firms are the last with 1.6 mil. MDL per enterprise. The difference in revenues by property types indicates rather different activities than ownership. It is more credible that foreign capital concentrates in the most profitable sectors of national economy (like communication and informatics) than that its simple presence increases firms' performance. 


\begin{abstract}
Across the categories the situation remains the same, enterprises with foreign participation occupies the top of hierarchies. Joint ventures are leading among medium-sized (23.3 mil. MDL) and small (5.8 mil. MDL) enterprises, while foreign firms occupy the first place among micro-enterprises (0.6 mil. MDL). Unlike firm size, companies with public capital operate with the lowest amounts of revenues irrespective of the ownership type, while private ones occupy intermediate position between the two big types. Last place of private companies in the entire SME sector statistics is explained by big number of private micro-enterprises that affect average figures of this firm type in the sector's average hierarchy. However, this deviation does not reflect real situation in the sector.
\end{abstract}

Same situation is observed in the hierarchy analyzing distribution of revenues per person. Enterprises with participation of foreign capital dominate both in entire SME sector and across the firms' categories. The difference between them and secondly placed private companies can achieve almost $50 \%$ (in the case of medium-sized enterprises), while in the case of public enterprises (which occupy the last place) this figure can be 3 times higher.

However, in terms of personnel efficiency private enterprises tend to occupy the leading role. As for the profit per employee, private firms occupy top of hierarchies in the most cases but one (medium-sized enterprises), when they are overpassed by joint ventures. In the entire SME sector there are 12 thou. MDL that fall at one employee of an average private enterprise. They are followed by mixed enterprises and joint ventures ( 9.9 and 9.8 thou. MDL accordingly), while a person in public enterprises has on average 5.5 thou. MDL; foreign enterprises close this hierarchy with just 2.9 thou. MDL per employee.

Examining this indicator across firm categories, we should emphasize the high efficiency of small private companies - 18 thou. MDL per employee - which is the highest figure. It is followed by small and medium-sized joint ventures with 13 thou. MDL per employee. Public companies have among the lowest values in all the categories.

Distribution of profitability is different from the one presented above. In this case, private companies have left the dominant position to enterprises with participation of public capital. In SME sector as a whole, mixed (public and private) companies have reached the profitability of $13 \%$, followed by public companies with $9 \%$. Private companies have achieved just $6 \%$, while enterprises with participation of foreign capital do not exceed $3.5 \%$.

In conclusion, we should say that there is no clear dominance of certain type of firms; however, some specific features can be pointed out. Public firms are usually bigger and have the highest profitability, but have the smallest turnover per firm. Private firms have the highest profit per employee, but are the smallest and the most dynamic. Firms with foreign capital usually operate with the largest amount of money; however, their profitability is the lowest.

Different types of capital are directed to different categories of enterprises. Thus, the public capital is directed more in creating small enterprises: $43 \%$ of all public enterprises are small (while mixed enterprises are distributed equally among the three categories, 1/3 each). Nonpublic types of capital prefer micro-enterprises as dominant category: their proportion is not less than $70 \%$, small enterprises occupy about $18-21 \%$.

Nevertheless, the largest proportion of revenues from sales falls with medium-sized enterprises for all types of ownership, excepting private. This proportion varies from $3 / 4$ for public enterprises to $1 / 2$ for foreign; small enterprises occupy second place with the range of $22-38 \%$. Microenterprises contribute with lesser share, from $1.6 \%$ (mixed capital) to $17 \%$ (foreign 
enterprises). In the case of private capital the contribution of the three categories of enterprises changes in favor of small enterprises $(47 \%)$ followed by medium-sized $(34 \%)$, the remaining share being supplied by micro-enterprises.

Across the ownership types, medium-sized enterprises contribute to profit by the greatest share $(63-82 \%)$, while small enterprises are on the second place $(18-37 \%)$. Only in the case of private and foreign enterprises, small companies contribute with the greatest share (about $50-60 \%)$. In all the ownership types micro-enterprises occupy the last place with small contribution to general profit that does not exceed 14\%. Moreover, companies with foreign capital have reported losses in the range from $7 \%$ (joint ventures) to $68 \%$ (foreign enterprises) of the total profit of each ownership type. However, reporting the losses does not mean that this type of capital, or this category of enterprises, has the highest investment risk, but the highest vulnerability. Conclusions about the profitability of certain type of company should be made after the long-term analysis at a more detailed level, for which we do not have enough data.

In terms of personnel efficiency, it looks like the hierarchy is stable across all the types of ownership: small firms have the biggest value of revenues per employee for each type of ownership; medium-sized companies occupy second place, while micro-enterprises are on the last place. In such a way, we have the right to say, to some extent, that small enterprises are the most efficient irrespective of the property type.

\section{Economic activity structure of SMEs}

Statistical data regarding activity of small and medium-sized enterprises are summarized into eight basic types of activity: agriculture, hunting, and forestry; manufacturing industry; electricity, heat, gas and water supply; construction; wholesale and retail trade; hotels and restaurants; transport and communications; real estate, renting and business services, as well as other activities.

Contribution to the market. In the SME sector as a whole, more than half of the sector's totals are due to the top three activity types: $60 \%$ of employees, $2 / 3$ of enterprises and profit, $78 \%$ of revenues are concentrated in them (table 3 ). These dominant activities are: trade (on the first place across all the indicators), followed by manufacturing industry, construction, real estate and business services, and agriculture (that occupies the $3^{\text {rd }}$ place just as number of employees). This situation reflects uneven distribution of SMEs in national economy, especially as for the domination of wholesale and retail trade.

Among medium-sized enterprises, agriculture and forestry occupy the leading position as regards number of enterprises and number of employees (28\% and $31 \%$ accordingly). However, as for turnover and profit, its place is taken by construction firms (the latter occupy $3^{\text {rd }}$ place in the hierarchy). Trade and industry have constant presence in the hierarchies: trade dominates as regards turnover and profit (46\% and $26 \%$ accordingly), while industry accedes to the second place with respect to the number of employees $(21 \%)$. In this category, it is difficult to point out the dominance of companies focused on trade activities, because of the dominance of agricultural activities in terms of the number of firms and employees. However, from the financial point of view, trade companies have the leading contribution to the category's totals. 
As for small enterprises, retail and wholesale activities bring the leading contribution to the category's totals: they have a share of $36 \%$ of enterprises (2.6 thou. firms), $28 \%$ of the number of employees (31 thou. people), $58 \%$ of the category's revenues (17.6 bil. MDL) and $41 \%$ of the profit (762 mil. MDL). Manufacturing industry follows them on the second place for all the indicators but profit: $15 \%, 19 \%$ and $13 \%$ accordingly, while as for the last indicator it is not even in the top three activities. Construction has important shares in the category's totals $\left(2^{\text {nd }}\right.$ and $3^{\text {rd }}$ places). However, we should point out here the role of real estate and business services: these firms are relatively numerous in this category ( $3^{\text {rd }}$ place -0.7 thou. firms); they neither attract too many employees, nor have the highest turnover, but have a $14 \%$ contribution to the profit per category (264 mil. MDL).

Among micro-enterprises, dominance of companies focused on trade activity is even more evident: $43 \%$ of the number of enterprises (13.1 thou. firms), $40 \%$ of the employees within this category ( 36 thou. people), $59 \%$ of revenues ( 6.9 bil. MDL), and $30 \%$ of category's profit (131 mil. MDL). However, real estate and business services have here a slightly greater contribution $(33 \%)$ to the profit, and, also, firms of this type a relatively numerous among microenterprises and attract quite big proportion of employees (both indicators equals $14 \%$, second place). Manufacturing industry occupies the $3^{\text {rd }}$ place for all the indicators but profit, where not just construction $\left(15 \%, 3^{\text {rd }}\right.$ place) overpasses it, but transport and agriculture as well.

Activity structure of the SME sector's enterprises in 2007

\begin{tabular}{|c|c|c|c|c|c|c|c|c|}
\hline \multirow{2}{*}{ Type of activity } & \multicolumn{2}{|c|}{$\begin{array}{l}\text { Number of } \\
\text { enterprises }\end{array}$} & \multicolumn{2}{|c|}{$\begin{array}{c}\text { Average number of } \\
\text { employees }\end{array}$} & \multicolumn{2}{|c|}{ Turnover } & \multicolumn{2}{|c|}{ Profit } \\
\hline & thou. units & $\%$ & thou. pers. & $\%$ & mil. $M D L$ & $\%$ & mil. $M D L$ & $\%^{*}$ \\
\hline $\begin{array}{l}\text { Agriculture, hunting and } \\
\text { forestry }\end{array}$ & 2.1 & 5.3 & 59.6 & 17.4 & 2871.2 & 4.3 & 380.4 & 10.1 \\
\hline Manufacturing industry & 5.0 & 12.7 & 63.0 & 18.3 & 9352.8 & 14.0 & 555.4 & 14.7 \\
\hline $\begin{array}{l}\text { Electricity and heat, gas and } \\
\text { water supply }\end{array}$ & 0.1 & 0.3 & 4.0 & 1.2 & 464.4 & 0.7 & -6.8 & \\
\hline Construction & 2.4 & 6.1 & 29.6 & 8.6 & 6553.4 & 9.8 & 611.4 & 16.2 \\
\hline Wholesale and retail trade & 16.1 & 41.0 & 84.2 & 24.5 & 35870.6 & 53.7 & 1287.1 & 34.0 \\
\hline Hotels and restaurants & 1.2 & 3.1 & 10.2 & 3.0 & 778.6 & 1.2 & 11.6 & 0.3 \\
\hline $\begin{array}{l}\text { Transport and } \\
\text { communications }\end{array}$ & 2.8 & 7.1 & 26.1 & 7.6 & 5345.6 & 8.0 & 223.6 & 5.9 \\
\hline $\begin{array}{l}\text { Real estate, renting and } \\
\text { business services }\end{array}$ & 5.2 & 13.2 & 32.9 & 9.6 & 3378.0 & 5.1 & 592.5 & 15.7 \\
\hline Other activities & 4.4 & 11.2 & 33.9 & 9.9 & 2172.0 & 3.3 & 122.3 & 3.2 \\
\hline Total SME & 39.3 & 100.0 & 343.5 & 100.0 & 66786.6 & 100.0 & 3777.5 & 99.8 \\
\hline
\end{tabular}

* Calculated as a part of total SME profit, excluding losses Source: National Bureau of Statistics

As for the organizational charts of the types of activity, medium-sized enterprises represent the preferential form of organization in agriculture and forestry: $74 \%$ of all the employees of this activity type work in medium-sized companies. However, the latter are the least numerous (just $24 \%$ ), while micro-enterprises have the greatest share $(48 \%)$. Because of this domination, medium-sized enterprises bring $57-60 \%$ of revenues and profit in agriculture and forestry type of activity, followed by small enterprises with a contribution of about $1 / 3$ of the activity type's totals.

In the manufacturing industry, the organizational chart is quite similar to the previous, but the dominance of medium-sized enterprises is not as evident: about $47 \%$ of workers (about 30 thou. people) in this category are employed in the medium-sized firms; $34 \%$ of employees 
work in in small companies. Against the previous activity type, the difference between contribution of medium-sized and small firms is not as bigger in this case: medium-sized firms have shares of $47 \%$ and $56 \%$ to revenues and profit, accordingly, while as for small companies this figures are just slightly less $-42 \%$ and $41 \%$. Here we can point out the clear outsider - micro-enterprises: their contribution to manufacturing industry type's totals is more important than in the case of agriculture; however, small firms, by their share of contribution, are much closer to the leading category than in the previous case.

Electricity, heat, gas and water repeat somehow the same structure, moreover, the organizational chart of this type is closer to agriculture than to industry: in the total number of 0.12 thou. companies, medium-sized enterprises occupy the leading position with $75 \%$ of employees and $87 \%$ of revenues. However, because of the small number of companies of this type, this structure is not as typical as in the previous two cases.

In their turn, construction activities follow the different organizational chart: it is close to some extent to the manufacturing industries (in terms of contribution shares), but two leading categories have changed their places. In the total number of 2.4 thou. construction companies there are about 100 medium-sized enterprises, 700 small and 1600 micro-enterprises. These prefer to organize in small firms ( $42 \%$ of employees), however, medium-sized enterprises are not left too far beyond (38\% of workers). As for turnover and profit, small companies have the largest contribution to the type's totals: $43 \%$ of turnover and $50 \%$ of profit.

Trade activities prefer the organizational chart based on rather "miniaturization" than large entities. Micro-enterprises attract $43 \%$ of employees in this activity type and represent $81 \%$ of the companies. However, their financial contribution is the lowest. Small enterprises have 50$60 \%$ contribution to revenues and profit, while medium-sized companies about $30 \%$. These figures show the situation in which trade activities are dominated by very small firms having one or several subsidiaries, while large trade networks or wholesale companies have the greatest financial contribution to the trade activity's totals.

Hotels and restaurants' organizational structure is quite similar to the trade's one (not in size, but in proportions). However, financial contribution of the medium-sized companies (about 30 firms) is, undoubtedly, the most important. Moreover, this category of firms was the only that had brought profit two years ago, while just micro-enterprises have ended the last year with losses.

In transport and communications there is no clear domination of any category of firms, however, the preference is given to bigger entities: medium-sized and small enterprises represent $3 / 4$ of all the companies within this activity type (about $40 \%$ medium-sized and $35 \%$ small). As for financial contribution, small companies have a slightly bigger share $(43-45 \%)$ than medium-sized ones (about 35-40\%). Micro-enterprises, although the most numerous $(3 / 4$ of all the transport companies), have the lowest financial importance for this activity type.

Apparently, real estate and business services have the most balanced organizational structure among all the presented types of activity: about $40 \%$ of employees prefer micro-enterprises, followed by $32 \%$ of those who prefer small firms, and $28 \%$ of people have chosen mediumsized companies. This way, micro-enterprises are the most numerous, but their financial contribution is the lowest (about $1 / 4$ ). Small enterprises have the biggest financial contribution of $45-46 \%$, while the share of medium-sized ones is about $30 \%$.

In conclusion, we can say that organization of production activities, including construction is 
based rather on larger firms, while services (excepting transport) prefer smaller companies. In the first case, medium-sized firms have the greatest financial contribution to the totals per activity type, while in the second case the situation is not as clear. If the business is not too risky (like trade or real estate services), small enterprises have the most important share in the totals, but if the business activities are vulnerable (like hotels and restaurants), medium-sized enterprises category represent sufficient assurance of ending the year with no losses.

Efficiency assessment. Average figures for the entire sector of SME show that the biggest companies are within the electricity, heat, gas and water sectors, about 40 people per enterprise. This figure results in the highest turnover per firm. Firms within this activity types are constantly unprofitable, however, in the last three years the unprofitability of these firms have been diminishing. In a couple of years, if the trend will not change, they will start bringing profit. As for firm size, the energy sector is followed by agriculture (28 people), manufacturing industry (13 people) and construction (12 people). Average size of the companies of other activity types is below 10 people; trade companies are the smallest, on average (5 people).

Trade, construction and transport operate with the highest turnover per person $(426 ; 221$ and 205 thou. MDL accordingly), for other types of activities these figures are below sectors' mean value. Highest personnel efficiency is characteristic to construction, real estate and business services, and trade due to high values (above average) of profit per person (21; 18 and 15 thou. MDL accordingly).

As for profitability, trade activities are not among the leading activities: their level is even below the SME average per sector $(3.6 \%)$. Here, the leading role is played by real estate and business services $(17.5 \%)$, which can be considered the most profitable type of activity, and, what is the most important, it is constant in bringing the profit (only construction has the similar constancy of profit dynamics). This activity type is followed, surprisingly, by agriculture (13\% profitability), and construction (9\%). In addition, manufacturing industry has its profitability above (but very close to) the sector's average. In fact, this order is maintained for all separate firm categories, excepting industry in the case of micro-enterprises.

Within the category of medium-sized enterprises construction, transport and electricity firms are the biggest (above $100 \mathrm{empl}$. per firm), while trade companies are the smallest, very close to the lower threshold. However, the latter have the greatest turnover per firm, followed by firms specialized in construction and transport services. Same order is kept as for the revenues per person and personnel efficiency: trade, the leading activity, showing 0.7 mil. MDL of revenues per person, and more than 23 thou. MDL of profit per person. As regards profitability, average figure for this category of enterprises equals $6 \%$, while in the case of business services it reaches its absolute maximum (18.3\%).

The biggest companies among small enterprises are specialized in hotels and restaurants services, electricity, industry and agriculture and are quite close in size to each other (cca1920 people per enterprise). Trade companies are the smallest, quite close to the category's lower threshold. As regards revenues per firm and per person, the order is the same as in the case of medium-sized companies, but with different figures. Trade, having the leading role, is characterized by 6.8 mil. MDL of revenues per firm and 570 thou. MDL per person. As for personnel efficiency, three activity types are above average and very close to each other (about 25 thou. MDL of profit per person): business services, having the leading role, are followed by construction and trade. The biggest figure of profitability, showed by business services, equals $17.2 \%$. 
Agriculture, electricity, construction, and hotels are the activity types, characterized by the biggest enterprises (about 4 people per firm) within the micro-enterprises category, in other types of activity average size is 3 people per firm. As regards revenues per firm and revenues per person, the top three activities are the same as in the two previous categories, but their order is different. Construction companies play the leading role as for revenues per firm (586 thou. MDL), followed by transport and trade, while as for revenues per person trade firms still keep their dominance, while construction is moved on the $3^{\text {rd }}$ place. Business services and construction activities are quite close as regards personnel efficiency (about 11 thou. MDL per person); agriculture is on the third place (8 thou. MDL).

Examining different activity types from the point of view of organizational efficiency, we can summarize that:

- $\quad$ small enterprises are the most efficient form of organization of the activities in agriculture and forestry because all the indicators show their maximum values. Although, the range of profitability is not very big (difference between categories is about $2.5 \%$ );

- $\quad$ medium-sized enterprises can better solve problems of losses in electricity, heat, gas, and water supply sector;

- $\quad$ both medium-sized and small enterprises can be considered as optimal organizational form for manufacturing industry as long as medium-sized companies have better values in profitability, while small ones are better in personnel efficiency;

- both medium-sized and small enterprises can be optimal for construction activities, how-ever small ones give slightly better results of profitability and personnel efficiency;

- $\quad$ same forms, as for previous activity type, can be recommended for trade activities: medium-sized and small enterprises present much better evolutions than microenterprises;

- there is no doubt that medium-sized enterprises optimally respond to the specific situation within the hotels and restaurants type of activity, at least they present much better assurance of obtaining the profit;

- $\quad$ for transport medium-sized and small enterprises can present better solution, however, micro-enterprises are not the worst choice as well;

- $\quad$ for real estate and business services it is the most difficult to point at the best category, however, small enterprises can be recommended as the optimal organizational form;

- $\quad$ summarizing, small enterprises represent the most optimal organizational form for economic activities in the SME sector in Moldova irrespective to the type of activity. However, this statement cannot be final as long as medium-sized enterprises have enjoyed business facility specific to the SME sector just since May 2006. At least 4-5 year period of constant economic conditions is needed for the analysis in order to strengthen (or change) the conclusion above.

With respect to the efficiency of economic activity, real estate, renting and business services have no rivals as for profitability and personnel efficiency within the SME sector. Construction companies are on the $2^{\text {nd }}$ place, presenting quite good figures of profitability and personnel efficiency. They are followed by wholesale and retail trade companies: profitability of these companies is quite low; they have high personnel efficiency and absolute incomes instead. Manufacturing industry and transport activities are very close to each other and can be considered as good for financial profitability as well.

Companies in agriculture and forestry have quite different situation in order to be presented above together with the other types of activity. In-depth analysis of their situation does not 
constitute subject of this paper, however some characteristic features and possible explanations should be pointed out.

Statistical data show that agricultural companies have ended last year on the second place among all the activity types as for profitability, and personnel efficiency at a quite good level as well (although with not very impressive absolute values). At the same time, in 2007 in Moldova a drought occurred, that has been the most severe since 1940s. Damages from the drought have reached 1 bil. USD (Drought in Moldova, 2008). Against this background, high values of agricultural enterprises' activity can be explained by two possible causes: (a) national and foreign aid has been included in certain way (directly or indirectly) among the results of economic activities of the enterprises, (b) recent rise of the prices on agricultural products on the world market, implicitly in Moldova, has reflected on the accounting balance of agricultural enterprises. In any case, this increase does not serve as start point of the new trend, and it is expected that the situation will return to the "normal", i.e. very low profitability level, especially since evidences of a similar trend in anterior evolutions of this sector are absent

\section{References}

BAUMOL W. J., (2004), Entrepreneurial enterprises, large establishments and other components of the freemarket innovation machine, Small Business Economics 23, p.9-21.

COOKE P. (2002), Knowledge economies: clusters, learning and cooperative advantage. London and NY: Routledge.

IANOŞ I., HELLER W. (2006), Spațiu, economie şi sisteme de aşezări, Edit. Tehnică, Bucureşti, (Space, economy, and settlement systems).

JEPPESEN S. (2005), Enhancing competitiveness and securing equitable development: can small, micro and medium-sized sized enterprises (SMEs) do the trick? Development in Practice 15(3-4), p. 463-474.

LA ROVERE R.L., HASENCLEVER L., ERBER F. (2004), Industrial and technology policy for regional development, Promoting clusters in Brazil, TMSD 2(3), p.205-217

LUNDVAL B.A., JOHNSON B. (1994), The learning economy, Journal of Industry Studies 1(2), p.23-42.

MOCANU G. (coord.) (2007), 100 cele mai presante probleme ale Republicii Moldova in 2007, Chisinau, IDIS-Viitorul (100 the most pressing Moldova's problems in 2007).

SîRODOEV I.G. (2006a), Procesele de integrare la nivelele superioare ale sistemului de aşezări al Republicii Moldova, Forum geografic, 1, p.48-53 (Integration processes at superior levels of Moldova's settlement system).

SîRODOEV I.G. (2006b), Procesele de fragmentare în sistemul de aşezări al Moldovei, Buletinul Academiei de Ştiințe a Moldovei. Ştiințele vieții, 2 (299), p.165-171, (Fragmentation processes in Moldova's settlement system).

SIRODOEV I.G. (2007), Regional development policy in the Republic of Moldova: Reconciling public administration and regional development reform, in: POP D. (ed.): Challenge of regional development in South-East Europe: Strategies for financing and service delivery. Budapest: FDI, http://lgi.osi.hu/publications datasheet.php?id=368.

VENKATARAMANAIAH S., PARASHAR S.P. (2007), Enhancing competitiveness of SMEs through industrial clusters, The Indian experience, TMSD 6(3), p.227-243.

VIRKKALA S. (2007), Innovation and networking in peripheral areas - a case study of emergence and change in rural manufacturing, European Planning Studies, 15(4), p. 511-529.

X X X (2002), Legea nr. 112-XII/20.05.1994 Cu privire la susținerea şi protecția micului business. MO 69/30.05.2002 (Law on small business support and protection).

$\mathrm{X} \times \mathrm{X}$ (2005), Commission of the European Communities, Implementing the Community Lisbon Programme: Modern SME Policy for Growth and Employment, Brussels, 
Igor G. SÎRODOEV

CEC

X X X (2006), Activitatea micului business în Republica Moldova în anul 2005. Notă informativă. BNS, http://www.statistica.md (Activity of the small business in Moldova in 2005).

X X X (2006), Global Economic Prospect: Economic Implications of Remittances and Migration, Washington, DC, World Bank.

X X X (2006), Legea nr. 206-XVI/7.07.2006 Privind susținerea sectorului întreprinderilor mici şi mijlocii. MO 126-130/11.08.2006 (Law on SME sector support).

X X X (2007), Activitatea întreprinderilor mici şi mijlocii în Republica Moldova în anul 2006. Notă informativă. BNS, http://www.statistica.md (Activity of the small and medium enterprises in Moldova in 2006).

X X X (2008), Activitatea întreprinderilor mici şi mijlocii în Republica Moldova în anul 2007. Notă informativă. BNS, http://www.statistica.md (Activity of the small and medium enterprises in Moldova in 2007).

X X X (2007), Strategia de susținere a dezvoltării întreprinderilor mici şi mijlocii pentru anii 2006-2008: Raport annual privind implementarea Strategiei în 2006. Chişinău: MEC, 2007 (Strategy on supporting SMEs development for 2006-2008: Annual report regarding implementation of the Strategy in 2006).

X X X (2008), Strategia națională de dezvoltare pe anii 2008-2011. MO 1820/29.01.2008 (National strategy of development for 2008-2011).

X X X (2008), Drought in Moldova, Internet site: http://www.un.md/droughts/ index.shtml. Last accessed on July 20th, 2008.

\section{Abbreviations:}

ATE - administrative-territorial entity

ATU - administrative-territorial unit

CRD - region of development „Center”

MDL - Moldavian leu

MEC - Minister of Economy and Trade

$\mathrm{MO}$ - Monitorul Oficial

NRD - region of development „North”

$\mathrm{RD}$ - regional development

SME - small and medium-sized enterprises

SRD - region of development „South”

USD - United States dollar 